\title{
DO POPULATIONS OF AN INVASIVE WEED DIFFER GREATLY IN THEIR PER-GRAM COMPETITIVE EFFECTS?
}

\author{
James E. Sowerwine ${ }^{1}$, Matthew J. Rinella ${ }^{2}$, and Matthew L. Carlson ${ }^{3}$
}

\begin{abstract}
Quantifying an invasive species' negative impacts across its introduced range will be quite challenging if the impacts vary unpredictably from site to site or from population to population. Little emphasis, however, has been placed on quantifying such interpopulation variation in the impacts of individual invasive species. We studied the response of a native grass (Festuca rubra) to competition from 4 geographically dispersed invasive plant (Melilotus albus) populations in order to determine if some populations of this invader have greater competitive impacts than others. Despite the relatively large number of experimental units in our greenhouse study, we did not obtain evidence that competitive effects per gram of biomass varied by invader population. Therefore, in some cases it should be possible to estimate the effects of invasive weeds with simple competition models that ignore some forms of phenotypic variation, as long as the models control for invader biomass per unit area (i.e., invader yield).
\end{abstract}

RESUMEN._Cuantificar los impactos negativos de una especie invasora a lo largo del rango en el que se ha introducido es bastante difícil si tales impactos varían impredeciblemente de un sitio a otro o de una población a otra. Sin embargo, poco ha sido el énfasis que se le ha dado a cuantificar tales variaciones interpoblacionales en los impactos de especies invasoras individuales. Estudiamos la forma en la que respondió una gramínea nativa (Festuca rubra) a la competencia generada por 4 poblaciones geográficamente dispersas de una planta invasora (Melilotus albus) con la finalidad de determinar si ciertas poblaciones de esta invasora tienen un impacto competitivo mayor que otras. A pesar del relativamente gran número de unidades experimentales en nuestro estudio de invernadero, no obtuvimos evidencia de que los efectos competitivos por gramo de biomasa variaran de acuerdo a cada población invasora. Por lo tanto, en algunos casos debe ser posible estimar los efectos de las malezas invasoras con modelos sencillos de competencia que ignoren algunas formas de variación fenotípica, siempre y cuando los modelos tomen en cuenta la biomasa del invasor por unidad de área (i.e., la productividad del invasor).

The competitive impact of an invasive weed on native plant communities can vary dramatically across sites (e.g., Rinella and Sheley 2005b: fig. 2; Thiele et al. 2010). This site-to-site variation in invader impacts is largely driven by differences in invader yield (i.e., invader biomass $\left[\mathrm{g} \cdot \mathrm{m}^{-2}\right.$ year $\left.\left.^{-1}\right]\right)$ because competitive impacts intensify with invader yield (Watkinson 1981; but see Parker et al. 1999, Vila et al. 2004, Meffin et al. 2010, Thiele et al. 2010) and invader yields vary widely across sites (e.g., Jacobs and Sheley 1999; Rinella and Sheley 2005a: fig. 1; Endress et al. 2007).

Since yield is so highly correlated with competitive impact, competition models typically use yield or related variables as predictors of competitive effect (Watkinson 1981, Cousens 1985, Freckleton and Watkinson 2001). When these models are used to estimate invasive weed impacts, they possess parameters quantifying how native plant performance (e.g., yield, cover) declines with increasing invader yield or measures related to yield (e.g., Parker et al. 1999, Rinella and Luschei 2007, Yokomizo et al. 2009, Thiele et al. 2010). The ultimate usefulness of these yield-impact models for estimating invasive weed impacts depends on the consistency of yield-impact relationships across invader populations and sites. Specifically, the usefulness of the models hinges on the assumption that a given invader yield causes the same impact on native plant performance across sites and invader populations. It is this assumption that allows yieldimpact models developed from data from one site to be used for estimating invader impacts at other sites (e.g., Rinella and Luschei 2007).

However, the assumption that different populations of an invader can be treated as uniform entities for purposes of estimating invader impacts has been brought into question (Lee 2002).

${ }^{1}$ University of Alaska Anchorage, Department of Biological Sciences, 3101 Science Circle, CPSB 101, Anchorage, AK 99508

${ }^{2}$ Corresponding author. USDA-ARS Fort Keogh LARRL, 243 Fort Keogh Road, Miles City, MN. E-mail: matt.rinella@ars.usda.gov

${ }^{3}$ Biological Sciences Department \& Alaska Natural Heritage Program, University of Alaska Anchorage, 707 A Street, Anchorage, AK 99501. 
Many factors suggest that different invader populations may differ in their yield-impact relationships. First, invader populations have been shown to differ phenotypically (e.g., Brodersen et al. 2008). Additionally, invaders commonly evolve new resource allocation strategies in their introduced ranges (Bossdorf et al. 2005), and the new strategies can vary across the introduced range ( $\mathrm{Xu}$ et al. 2010). Increased allocation to vegetative growth and decreased allocation to defense appear to be somewhat common adaptations in genetically isolated populations (Bossdorf et al. 2005). Similarly, different populations of the same species can differ in factors like growth form (e.g., Barrett 1983, Ransom et al. 1998) and water-use efficiency (Heschel et al. 2002), and these differences may cause variation in yieldimpact relationships in cases where there is competition for light or water. Finally, a few studies have already illustrated among-species differences in yield-impact relationships (Goldberg and Fleetwood 1987, Howard 2001, Hager 2004), which provides additional evidence that genetically or phenotypically dissimilar populations of a given species may also differ appreciably in their yield-impact relationships. At the same time, a larger number of studies failed to show differences among the yieldimpact relationships of noninvasive plant species (Goldberg and Werner 1983, Goldberg 1987, Gaudet and Keddy 1988). These studies certainly cast doubt on the idea that different populations of the same invader differ substantially in their yield-impact relationships. In summary, it remains unclear whether or not a given biomass of an invasive plant has a uniform competitive impact across sites, regardless of the invader's evolutionary and introduction history.

Our goal was to determine if 4 geographically dispersed invasive plant populations vary appreciably in their yield-impact relationships. In a greenhouse, we varied the seed density of the invasive populations and the seed density of a native target species. The invader was the short-lived perennial Melilotus albus gathered from 4 seed source populations across its Alaskan range. Multiple $M$. albus cultivars that were developed in the U.S. and Canada escaped from 4 Alaskan agricultural experiment stations between 1913 and 1944; thus, the Alaskan populations likely derive from several different sources (Irwin 1945, Klebesadel 1992).
Additionally, the populations had experienced greatly dissimilar climatic conditions since introduction, and there is evidence that $M$. albus rapidly adapts to local conditions (Klebesadel 1992), further raising the potential that the populations have evolved different competitive abilities.

\section{Methods}

Melilotus albus seeds were collected from a number of parent plants along rivers: 81 plants in southeast Alaska (Stikine River: $58.02^{\circ} \mathrm{N}$, $\left.133.31^{\circ} \mathrm{W}\right), 25$ in south central Alaska (Matanuska River: $\left.61.30^{\circ} \mathrm{N}, 149.05^{\circ} \mathrm{W}\right), 30$ in southern interior Alaska (Healy River: $63.51^{\circ} \mathrm{N}, 148.55^{\circ} \mathrm{W}$ ), and 8 in northern interior Alaska (Ray River: $\left.65.56^{\circ} \mathrm{N}, 150.06^{\circ} \mathrm{W}\right)$. The populations were separated by a minimum of $250 \mathrm{~km}$. These areas range in mean annual temperature from approximately $-5{ }^{\circ} \mathrm{C}$ to $+5{ }^{\circ} \mathrm{C}$ and in precipitation from approximately $700 \mathrm{~mm}$ to $2500 \mathrm{~mm}$ per year. In 2007, seeds from each of these 4 populations were evenly sown on the soil surface of pots after being scarified with 100-grit sandpaper for 5 minutes. Seeds of a native grass (Festuca rubra) that commonly establishes with $M$. albus on recently exposed Alaskan floodplains were also evenly sown in the pots. The species were planted in a replacement series at 4 densities to produce a range of inter- and intraspecific competition. Seed density combinations (M. albus : F. rubra) were 1:3, 2:2, 3:1, $4: 12,6: 18,8: 8,9: 27,12: 4,12: 12,18: 6,18: 18$, and 27:9. These combinations and densities were similar to those in a native legume-Melilotus albus experiment published by Spellman (2008). Each density combination was replicated 10 times, as was a 0:1 density combination (4 populations $\times 12$ density combinations $\times 10$ replications + ten $0: 1$ pots $=490$ pots). The square pots $(8.5 \mathrm{~cm}$ per side, $10 \mathrm{~cm}$ tall $)$ contained $50 \%$ Sunshine \# 1 potting mix and $50 \%$ coarse sand. The pots were arranged in a completely randomized design in a greenhouse maintained at $20^{\circ} \mathrm{C}$ with an 18 -hour daylight period. Pots were watered as needed throughout the experimental period. Sixty days after seeding, plants were harvested, sorted by species, and weighed after drying to constant weight at $45^{\circ} \mathrm{C}$.

The following fixed-effects linear regression model was used to describe the data:

$$
\ln y_{i}=N\left(\mu+\alpha \cdot \ln Z_{i}+\beta_{j(i)} \cdot X_{i}, \sigma\right),
$$




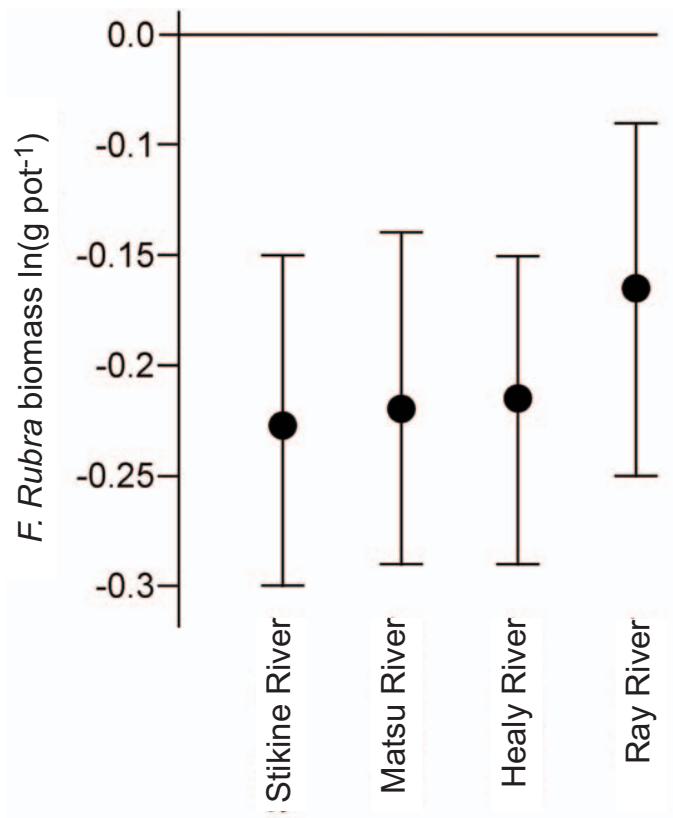

Fig. 1. Least-squares parameter estimates (dots) and $95 \%$ confidence intervals (bars) estimating decreases in biomass per pot of a native grass (Festuca rubra) caused by increases of $1 \mathrm{~g}$ per pot in the biomass of an invasive weed (Melilotis albus).

where $y_{i}$ is F rubra biomass in pot $i, N(\mu, \sigma)$ is the normal distribution with mean $\mu$ and standard deviation $\sigma ; \mu$ is the intercept; $Z_{i}$ is $F$. rubra seeding density in pot $i$; $\alpha$ controls for the effect of F. rubra density; and $X_{i}$ is $M$. albus biomass in pot $i$. The $\beta$ vector contains one element for each $M$. albus population, and the $j(i)$ indicator function maps data points to populations. For example, $j(22)=$ Stikine River. Finally, $\sigma$ is the random error standard deviation. Statistical analysis was performed in Microsoft Excel 2007 Analysis Pack. Modeling assumptions of linearity, homoscedasticity of errors, and normality of the error distribution were assessed graphically (predicted vs. observed values).

\section{RESULTS}

Least-squares parameter estimates and 95\% confidence intervals describing competitive effects of $M$. albus on F. rubra were confined to negative ranges for all $M$. albus populations, indicating that all 4 populations of the invader negatively impacted F. rubra growth (Fig. 1). The least-squares parameter estimates also suggested that each $1-\mathrm{g}$ increase in M. albus caused a
16\%-23\% decrease in F. rubra weight per pot. The high degree of overlap among confidence intervals indicated that competitive effects of M. albus on F. rubra did not vary greatly among the 4 M. albus populations (Fig. 1).

\section{Discussion}

Despite its large number of replications and density treatments, our study did not provide evidence that per-gram competitive effects of M. albus vary appreciably across populations (Fig. 1). Confidence intervals for the 4 study populations overlap substantially.

It is not completely surprising that we did not detect differences in per-unit-biomass competitive effects within a species, even though the populations were genetically isolated and likely experienced different selection pressures. Attempts to detect differences in per-unit-biomass competitive effects among species have given mixed results, and most differences appear to be among species of different growth forms (e.g., grasses vs. forbs; Goldberg and Fleetwood 1987). Among plants of the same growth form, differences in competitive ability resulting from differences in per-unit-biomass competition are hypothesized to be relatively unimportant compared to differences in competitive ability resulting from plant size asymmetries (Goldberg and Werner 1983).

Our data suggest that, after controlling for M. albus yield, M. albus populations do not differ greatly in their competitive impacts on native species. Therefore, variation among populations of an invader may not greatly reduce the accuracy of models used for estimating invasive weed impacts, provided the models control for invader yield.

However, a few caveats need to be considered. First, despite our large number of experimental units, the confidence intervals are still fairly wide, spanning roughly 0.3 units. Larger studies could reveal potentially important differences in yield-impact relationships. Next, we measured competitive responses of only one target species, and these responses may vary by target species (Goldberg and Landa 1991). Also, competitive responses can vary with environmental conditions (Wang et al. 2010), so the effect of $M$. albus competition on any one native species may vary with nutrient concentrations or other environmental variables. Moreover, genotypes of some species produce different amounts 
and kinds of allelochemicals (Wu et al. 1999, Han and Ju 2005), which may lead to appreciable variation in per-unit-biomass competitive effects within some species. Finally, resourceuse efficiencies (i.e., resource uptake per unit biomass) do vary among populations of some species (e.g., Heschel et al. 2002), and this variation could translate into interpopulation variation in per-unit-biomass competitive effects of some species. Our study may have masked differences in water-use efficiencies because we watered on an "as needed" basis, thereby ensuring that water did not limit plant growth.

These caveats aside, the result that genetically isolated invader populations occurring across an expansive geographic range have roughly uniform per-gram competitive effects on a native species supports the idea that yield-impact relationships are fairly consistent across sites and populations. Therefore, at least for these species, measures of an invader's competitive impacts at one site may accurately predict its competitive impacts at other sites throughout the invaded range, provided that differences in invader yield among the sites are controlled.

\section{ACKNOWLEDGMENTS}

Chad Cook, Jeff Conn, Jill Yarbrough, Katie Villiano, and the Alaska Plant Materials Center assisted with seed collections. The University of Alaska Anchorage Engineering Department supplied greenhouse space. Jeff Conn and Steve Seefeldt provided valuable input on drafts of the manuscript. We gratefully acknowledge support from the Alaska EPSCoR (NSF and Alaska State award \#EPS-0701898) and the Alaska Natural Heritage Program, UAA.

\section{Literature Cited}

BarRett, S.C.H. 1983. Crop mimicry in weeds. Economic Botany 37:255-282.

Bossdorf, O., H. Auge, L. Lafuma, W.E. Rogers, E. SieMANN, AND D. Prati. 2005. Phenotypic and genetic differentiation between native and introduced plant populations. Oecologia 144:1-11.

Brodersen, C., S. Lavergne, and J. Molofsky. 2008. Genetic variation in photosynthetic characteristics among invasive and native populations of reed canarygrass (Phalaris arundinacea). Biological Invasions 10: 1317-1325.

Cousens, R. 1985. A simple model relating yield loss to weed density. Annals of Applied Biology 107:239-252.

ENDRESS, B.A., B.J. NAYLOR, C.G. PARKS, AND S.R. RADOSEVICH. 2007. Landscape factors influencing the abundance and dominance of the invasive plant Potentilla recta. Rangeland Ecology and Management 60:218-224.
Freckleton, R.P., AND A.R. Watkinson. 2001. Nonmanipulative determination of plant community dynamics. Trends in Ecology and Evolution 16:301-307.

GaudeT, C.L., AND P.A. KEDDY. 1988. Predicting competitive ability from plant traits: a comparative approach. Nature 334:242-243.

GoldBERG, D.E. 1987. Neighborhood competition in an old-field plant community. Ecology 68:1211-1223.

GoldberG, D.E., AND L. FleEtwood. 1987. Competitive effect and response in four annual plants. Journal of Ecology 75:1131-1143.

GoldBerG, D.E., and K. LANDA. 1991. Competitive effect and response: hierarchies and correlated traits in the early stages of competition. Journal of Ecology 79: 1013-1030.

Goldberg, D.E., AND P.A. Werner. 1983. Equivalence of competitors in plant communities: a null hypothesis and a field experimental approach. American Journal of Botany 70:1098-1104.

HaGER, H.A. 2004. Competitive effect versus competitive response of invasive and native wetland plant species. Oecologia 139:140-149.

HAN, L., AND H. Ju. 2005. Allelopathy of root exudates from two genotypes soybeans on root pathogenic fungi. Ying Yong Sheng Tai Xue Bao 16:137-141.

Heschel, M.S., K. Donohue, N. Hausmann, and J. SCHмITT. 2002. Population differentiation and natural selection for water-use efficiency in Impatiens capensis (Balsaminaceae) International Journal of Plant Sciences 163:907-912.

HowARD, T.G. 2001. The relationship of total and per-gram rankings in competitive effect to the natural abundance of herbaceous perennials. Journal of Ecology 89:110-117.

IRWIN, D.L. 1945. Forty-seven years of experimental work with grasses and legumes in Alaska. University of Alaska Agricultural Experiment Station Bulletin 12: 4-45.

JACOBS, J.S., AND R.L. Sheley. 1999. Spotted knapweed forb, and grass response to 2,4-D and N-fertilizer. Journal of Range Management 52:482-488.

KLEBESADEL, L.J. 1992. Morphological, physiological, and winterhardiness comparisons among latitudinal ecotypes of biennial sweetclover (Melilotus species) in subarctic Alaska. University of Alaska Agricultural Experiment Station Bulletin 91:1-27.

LEE, C.E. 2002. Evolutionary genetics of invasive species. Trends in Ecology and Evolution 17:386-391.

Meffin, R., A.L. Miller, P.E. Hulme, and R.P. Duncan. 2010. Experimental introduction of the alien plant Hieracium lepidulum reveals no significant impact on montane plant communities in New Zealand. Diversity and Distributions 16:804-815.

Parker, I.M., D. Simberloff, W.M. Lonsdale, K. Goodell, M. Wonham, P.M. Kareiva, M.H. Williamson, B. Von Holle, P.B. Moyle, J.E. Byers, and L. GoldWASSER. 1999. Impact: toward a framework for understanding the ecological effects of invaders. Biological Invasions 1:3-19.

Ransom, C.V., J.J. Kells, L.M. WaX, and M.S. Orfanedes. 1998. Morphological variation among hemp dogbane (Apocynum cannabinum) populations. Weed Science 46:71-75.

Rinella, M.J., AND E.C. Luschei. 2007. Hierarchical Bayesian methods estimate invasive weed impacts at pertinent spatial scales. Biological Invasions 9: $545-558$. 
Rinella, M.J., AND R.L. Sheley. 2005a. A model for predicting invasive weed and grass dynamics. I. Model development. Weed Science 53:586-593.

$2005 \mathrm{~b}$. A model for predicting invasive weed and grass dynamics. II. Accuracy evaluation. Weed Science 53:605-614.

SPELLMAN, B.T. 2008. The impact of invasive sweetclover (Melilotus alba) in early-successional floodplain habitats of Alaska. Master's thesis, University of Alaska Fairbanks, Fairbanks, AK

Thiele, J., J. Kollmann, B. Markussen, and A. Otte. 2010. Impact assessment revisited: improving the theoretical basis for management of invasive alien species. Biological Invasions 12:2025-2035.

Vila, M., M. Williamson, and M. Lonsdale. 2004. Competition experiments on alien weeds with crops: lessons for measuring plant invasion impact? Biological Invasions 6:59-69.

Wang, P., T. Stieglitz, D.W. Zhou, AND J.F. Cahill. 2010. Are competitive effect and response two sides of the same coin, or fundamentally different? Functional Ecology 24:196-207.

Watkinson, A.R. 1981. Interference in pure and mixed populations of Agrostemma githago L. Journal of Applied Ecology 18:967-976.

Wu, H., J. Pratley, D. Lemerle, and T. Haig. 1999. Crop cultivars with allelopathic capacity. Weed Research 39:171-180.

Xu, C.Y., M.H. Julien, M. Fatemi, C. Girod, R.D. Van Klinken, C.L. Gross, and S.J. NovaK. 2010. Phenotypic divergence during the invasion of Phyla canescens in Australia and France: evidence for selection-driven evolution. Ecology Letters 13:32-44.

Yokomizo, H., H.P. Possingham, M.B. Thomas, and Y.M. BuCKLEY. 2009. Managing the impact of invasive species: the value of knowing the density-impact curve. Ecological Applications 19:376-386.

Received 3 March 2011 Accepted 21 November 2011 